\title{
KOMPOSISI PROKSIMAT DAN INDEKS GLIKEMIK NIRA AREN
}

PROXIMATE COMPOSITION AND PALM JUICE GLYCEMIC INDEX

Yurnia Ningsih N. Ismail, Margaretha Solang , Wirnangsih D. Uno

Universitas Negeri Gorontalo

Email: margarethasolang@ung.ac.id

\begin{abstract}
This research intended to evaluate the proximate composition and palm juice glycemic index. The analysis of water, protein, and ash contents used the oven, semi-micro Kjeldahl, and thermogravimetry methods, respectively. Meanwhile, fat, carbohydrate, and sugar contents were analyzed by relying on direct extrusion method with a Soxhlet, by difference method, and Luff Schoorl method, respectively. Further, the analysis of the glycemic index employed the calculation of area under the curve using the finger-prick capillary blood method. The measurement of blood glucose levels was done to ten respondents who were given pure glucose and palm juice. The results revealed that palm juice contained $91.1 \%$ water, $0.28 \%$ ash, $0.41 \%$ protein, $0 \%$ fat, $8.21 \%$ carbohydrate, and $0,67 \%$ sugar. The average blood glucose of the respondents after consuming pure glucose and palm juice in minute $0,30,60,90$, and 120 arrived at $93.2 \mathrm{mg} / \mathrm{dL}, 155.4 \mathrm{mg} / \mathrm{dL}, 124.2 \mathrm{mg} / \mathrm{dL}, 93.8 \mathrm{mg} / \mathrm{dL}, 79.1 \mathrm{mg} / \mathrm{dL}$, and $81.8 \mathrm{mg} / \mathrm{dL}$, $118.6 \mathrm{mg} / \mathrm{dL}, 92.6 \mathrm{mg} / \mathrm{dL}, 74.1 \mathrm{mg} / \mathrm{dL}$, and $63.7 \mathrm{mg} / \mathrm{dL}$. The value of the palm juice glycemic index was 35.56 (low category), so that this juice could function as an alternative drink to maintain blood glucose levels.
\end{abstract}

Keywords: Proximate Composition, Glycemic Index, Palm Juice.

\begin{abstract}
Abstrak Penelitian ini bertujuan untuk mengevaluasi komposisi proksimat dan nilai indeks glikemik nira aren. Analisis kadar air menggunakan metode oven, protein menggunakan metode semimikro kjeldhal, kadar abu menggunakan metode thermografimetri, dan lemak menggunakan metode ekstruksi langsung dengan alat soxhlet, karbohidrat menggunakan metode by difference, dan gula mengunakan metode Luff schoorl . Analisis indeks glikemik menggunakan perhitungan luas area dibawah kurva menggunakan metode finger-prick capillary blood. Pengukuran kadar glukosa darah pada 10 orang responden yang diberi glukosa murni dan nira aren. Hasil penelitian menunjukkan nira aren mengandung 91,1\% air, 0,28\% kadar abu, 0,41\% protein, $0 \%$ lemak, 8,21\% karbohidrat dan $0,67 \%$ jumlah gula. Rata-rata glukosa darah responden setelah mengkonsumsi glukosa murni dan nira aren pada menit ke-0, 30, 60, 90, 120 yaitu sebagai berikut 93,2 mg/dL, 155,4 mg/dL, 124,2 mg/dL, 93,8 mg/dL, 79,1 $\mathrm{mg} / \mathrm{dL}$, dan $81,8 \mathrm{mg} / \mathrm{dL}, 118,6 \mathrm{mg} / \mathrm{dL}, 92,6 \mathrm{mg} / \mathrm{dL}, 74,1 \mathrm{mg} / \mathrm{dL}$, dan 63,7 mg/dL. Nilai indeks glikemik nira aren adalah 35,56 berada pada kategori rendah, sehingga nira aren merupakan minuman alternatif untuk menjaga kadar gula darah
\end{abstract}

Kata Kunci: Komposisi Proksimat, Indeks Glikemik, Nira Aren 


\section{PENDAHULUAN}

Glukosa darah adalah konsentrasi gula dalam darah, atau tingkat glukosa serum diatur ketat dalam tubuh. Glukosa yang dialirkan dalam darah adalah sumber utama energi untuk sel-sel dalam tubuh. Glukosa adalah bahan bakar utama bagi kebanyakkan jaringan. Pada keadaan pasca penyerapan, kadar glukosa darah dipertahankan antara 4,5-5,5 mmol/L. setelah mengkonsumsi karbohidrat, kadar tersebut dapat meningkat menjadi 6,5-7,2 $\mathrm{mmol} / \mathrm{L}$, dan pada saat kelaparan kadarnya dapat turun menjadi 3,3-3,9 $\mathrm{mmol} / \mathrm{L}$ (Murray, 2009). Menurut Price (2005), kadar gula darah setiap hari bervariasi dan akan meningkat setelah mengkonsumsi makanan atau minuman cairan yang mengandung gula maupun karbohidrat lainnya dan akan kembali pada keadaan normal dalam waktu 2 jam.

Asupan karbohidrat yang berlebihan akan meningkatkan sekresi insulin, akhirnya insulin tidak mampu melaksanakan tugasnya lagi untuk menjaga kadar glukosa darah pada taraf normal. Oleh karena itu, dibutuhkan cara untuk mengontrol glukosa darah salah satunya, yaitu dengan pengaturan makan atau diet menggunakan konsep indeks glikemik. Indeks Glikemik (IG) merupakan nilai yang menunjukkan kemampuan suatu makanan yang mengandung karbohidrat dalam meningkatkan kadar gula darah. Konsep indeks glikemik, menurut Arif dkk (2013) sebagai alat untuk mengukur respon glukosa darah terhadap karbohidrat pada jenis makanan yang dikonsumsi. Menurut Baclay et al (2008), Perhitungan Indeks Glikemik pada suatu makanan yang mengandung karbohidrat adalah dengan membandingkan luas area dibawah kurva respon glukosa darah pangan uji dengan luas area dibawah kurva respon glukosa darah pangan standar.

Makanan berindeks glikemik tinggi akan menaikkan glukosa darah dengan cepat, sedangkan makanan yang berindeks glikemik rendah akan menaikkan kadar gula darah dengan lambat (Rimbawan \& Siagian, 2004). Penelitian menunjukkan makanan yang memiliki indeks glikemik rendah mampu memperbaiki sensivitas insulin dan menurunkan laju penyerapan glukosa, sehingga dapat bermanfaat untuk mengendalikan kadar gula darah (Riccadi et al, 2013). Makanan yang berindeks glikemik tinggi berpengaruh pada peningkatan kecepatan dan menambah jumlah kadar glukosa dalam darah secara cepat. Nilai
IG dalam suatu makanan yaitu $\geq 70$ tergolong tinggi, sedangkan 56-69 sedang dan $\leq 55$ rendah (Ostman, 2001).

Salah satu bahan yang memiliki IG rendah adalah gula aren kristal. Berdasarkan penelitian Riawan (2017), bahwa gula aren kristal memiliki IG rendah dengan nilai 43.61 dan gula aren cetak memiliki IG sedang dengan nilai 62.47. Gula aren oleh masyarakat dibuat dari bahan dasarnya nira aren. Nira aren merupakan suatu produk yang sangat penting karena mengandung gula yang dapat digunakan untuk menghasilkan gula aren ataupun dapat difermentasikan menjadi etanol. Kandungan kimia lain yang terdapat pada nira aren yaitu protein, energi, serat dan vitamin. Kadar protein dalam nira berhubungan dengan metabolisme enzimatis gula sehingga kandungan protein dapat digunakan untuk memperkirakan produktivitas gula dalam nira (Pontoh, 2011). Menurut Pontoh (2007), nira aren yang segar mengandung 13,9-14,9\% sukrosa, $0,04 \%$ kadar abu, dan $0,02 \%$ kadar lemak. Protein dalam nira aren berasal dari empulur aren. Sekalipun protein dalam nira aren relatif sangat kecil, namun jika dihitung dari total bahan kering, kandungan protein bisa mencapai $0,78 \%$.

Berdasarkan observasi di Kecamatan Telaga Biru Kabupaten Gorontalo nira aren sangat digemari oleh masyarakat karena dapat dikonsumsi secara langsung dan diyakini oleh masyarakat sebagai alternatif untuk dapat menurunkan kadar glukosa darah. Untuk mendukung potensi nira aren sebagai minuman alternatif bagi penderita diabetes, maka perlu dilakukan uji indeks glikemik. Penelitian ini bertujuan untuk mengevaluasi komposisi proksimat dan nilai indeks glikemik nira aren.

\section{METODOLOGI}

Penelitian dilaksanakan pada bulan OktoberNovember 2019. Nira aren diperoleh dari Kecamatan Telaga Biru Kabupaten Gorontalo. Analisis proksimat dilakukan di Laboratorium Analisis dan Kalibrasi Balai Besar Industri Agro Bogor. Uji Indeks Glikemik di laksanakan di Laboratorium Biokimia Jurusan Biologi Fakultas Matematika dan Ilmu Pengetahuan Alam Universitas Negeri Gorontalo. Pangan standar yang digunakan adalah glukosa murni, sedangkan pangan uji adalah nira Aren. Alat penelitian, yaitu botol timbang tertutup, eksikator, oven, cawan porselen atau platina, tanur listrik, labu Kjeldhal $100 \mathrm{~mL}$, alat penyulingan dan kelengkapannya, pemanas 
listrik/pembakar, labu lemak, soxhlet, Erlenmeyer $500 \mathrm{~mL}$, pipet volumetrik $10 \mathrm{~mL}$, $25 \mathrm{~mL}$, dan $50 \mathrm{~mL}$, labu ukur 100 dan $250 \mathrm{~mL}$, penangas air, pendingin tegak, thermometer, dan buret $50 \mathrm{~mL}$, spektrofotometer pada panjang gelombang $630 \mathrm{~nm}$, alat gelas ukur, gelas plastik, pengukur glukosa darah (nesco), strip glukosa darah, timbangan berat badan, alat pengukur tinggi badan, bloodlancet, neraca analitik, stopwatch.

Bahan yang digunakan yaitu campuran $2,5 \mathrm{~g}$ serbuk $\mathrm{S}_{\mathrm{e}} \mathrm{O}_{2}, 100 \mathrm{~g} \mathrm{~K}_{2} \mathrm{SO}_{4}$ dan $20 \mathrm{~g}$ $\mathrm{CuSO}_{4} 5 \mathrm{H}_{2} \mathrm{O}$, larutan bromocresol green $0,1 \%$, larutan merah metal 0,1\% dalam alkohol 95\%, larutan asam borat $\mathrm{H}_{3} \mathrm{BG}_{3} 2 \%$, larutan asam klorida $\mathrm{HCl} 0,01 \mathrm{~N}$, larutan natrium hidroksida $\mathrm{NaOH} 30 \%$, kertas lakmus, n-heksana atau pelarut lemak lainnya, larutan asam klorida $\mathrm{HCl}$ $25 \%$, larutan kalium iodida KI 20\%, larutan asam sulfat $\mathrm{H}_{2} \mathrm{SO}_{4} 25 \%$, larutan natrium tiosulfat $\mathrm{Na}_{2} \mathrm{~S}_{2} \mathrm{O}_{3} 0,1 \mathrm{~N}$, indikator kanji $0,5 \%$, larutan natrium hidroksida $\mathrm{NaOH} 4 \mathrm{~N}$, larutan indikator fenolftalin, $0,1 \mathrm{~g}$ glukosa, aquadest, 5 $\mathrm{mL}$ pereaksi anthrone, $5 \mathrm{~mL}$ filtrat, $\mathrm{HCl} 3 \mathrm{ml}$, larutan timbal asetat setengah basa atau larutan seng asetat, dan larutan ammonium hydrogen fosfat $\left(\mathrm{NH}_{4}\right)_{2} \mathrm{HPO}_{4} 10 \%$ atau larutan kalium ferosianida, kapas, alkohol instant, aluminium foil, glukosa murni, nira aren dan air mineral.

Analisis kadar air menggunakan metode oven, protein menggunakan metode semimikro kjeldhal, kadar abu menggunakan metode thermografimetri, dan lemak menggunakan metode ekstruksi langsung dengan alat soxhlet dengan uji SNI 01-28911992. Karbohidrat menggunakan metode by difference dengan uji IK 7.2.3 dan gula mengunakan metode Luff schoorl dengan uji SNI 01-2892-1992, butir 3.1.

\section{Penentuan Jumlah Pangan Uji}

Pangan yang akan dinilai indeks glikemiknya adalah Nira aren. Sedangkan, bahan pangan acuan yang akan digunakan adalah glukosa murni. Jumlah nira aren yang diberikan dihitung berdasarkan kesetaraan dengan $25 \mathrm{~g}$ karbohidrat glukosa murni dan untuk bahan pangan uji ditentukan dengan menggunakan rumus dibawah ini menurut (Budijanto dkk, 2017).

$$
\begin{gathered}
\text { Jumlah sampel }(g)=\frac{25 g}{\text { Karbohidrat sampel }} \times \\
100 \%
\end{gathered}
$$

\section{Uji Nilai Indeks Glikemik}

Responden uji indeks glikemik adalah 10 orang mahasiswa Jurusan Biologi Fakultas Matematika dan IPA Universitas Negeri Gorontalo. Kriteria inklusi dan eksklusi untuk responden yaitu orang dewasa sehat dengan populasi mahasiswa (18-25 tahun), memiliki indeks massa tubuh normal $\left(18,5 \mathrm{~kg} / \mathrm{m}^{2}\right.$ dan $24,9 \mathrm{~kg} / \mathrm{m}^{2}$ ) kriteria Asia-Pasifik, tidak memiliki riwayat gangguan metabolisme glukosa, dalam keadaan sehat,dan tidak menjalani program diet dalam 3 bulan terakhir.

Pengumpulan data dilakukan setelah dilakukan anamnesis yang meliputi identitas diri, riwayat penyakit, pengukuran berat badan dan tinggi badan, serta mendapatkan persetujuan responden dan mengisi lembar inform consent. Sebelum pemeriksaan glukosa darah, responden berpuasa selama 10 jam dimalam hari, makan dengan porsi normal sebelum puasa, dan tidak melakukan aktivitas berat. Pengukuran glukosa darah responden yang mengkonsumsi pangan standar (glukosa murni) dilakukan pada 10 orang responden pada pagi harinya dengan pengambilan sampel darah kapiler pada menit ke-0, 30, 60,90, dan 120. Pengujian untuk nira aren dilakukan pada hari ke empat setelah konsumsi pangan standar dengan diberikan air putih 250-500 mL air.

Kadar gula darah (pada setiap waktu pengambilan sampel) ditebar pada dua sumbu, yaitu sumbu waktu $(\mathrm{X})$ dan kadar gula darah (Y). Indeks glikemik ditentukan dengan membandingkan luas daerah di bawah kurva antara pangan uji dengan pangan acuan (glukosa murni) dikalikan 100. Perhitungan luas area di bawah kurva menggunakan metode Brouns et al (2005), dengan rumus :

$$
\begin{aligned}
\mathrm{L}=\frac{\Delta 30 t}{2}+\Delta & 60 t+\frac{(\Delta 30-\Delta 60) t}{2}+\Delta 90 t \\
+ & \frac{(\Delta 60-\Delta 90) t}{2}+\Delta 120 t \\
+ & \frac{(\Delta 90-\Delta 120) t}{2}
\end{aligned}
$$

Keterangan :

$$
\begin{aligned}
& \text { L = Luas area di bawah kurva } \\
& \mathrm{t}=\text { Interval waktu pengambilan darah } \\
& \text { (30 menit) } \\
& \Delta 30=\text { Selisih kadar glukosa darah } 30 \text { menit } \\
& \text { setelah beban dengan puasa } \\
& \Delta 60=\text { Selisih kadar glukosa darah } 60 \text { menit } \\
& \text { setelah beban dengan puasa } \\
& \Delta 90=\text { Selisih kadar glukosa darah } 90 \text { menit } \\
& \text { setelah beban dengan puasa } \\
& \Delta 120=\text { Selisih kadar glukosa darah } 120
\end{aligned}
$$


menit setelah beban dengan puasa.

Perhitungan indeks glikemik (IG) dilakukan dengan cara membandingkan luas kurva antara sampel pangan uji (nira aren) dan luas kurva pangan acuan (glukosa murni). Berikut ini merupakan rumus untuk menentukan indeks glikemik pangan menurut Lestari,dkk (2017) yaitu :

$$
\mathrm{IG}=\frac{\text { Luas kurva sampel }}{\text { Luas kurva standar }(\text { glukosa murni })}
$$

\section{HASIL DAN PEMBAHASAN Komposisi proksimat nira aren}

Nira aren dihasilkan dari pohon aren. Nira aren adalah produk yang penting karena kandungan gulanya dapat digunakan untuk menghasilkan gula aren. Menurut Widyawati (2012), Nira aren merupakan hasil dari penyadapan pada bagian tandan bunga jantan atau bunga betina. Namun, dengan pertimbangan kelangsungan populasi aren maka yang diambil niranya adalah bunga jantan sehingga bunga betina tetap bisa menghasilkan buah dan biji. Nira aren segar berasa manis, berbau khas nira dan jernih. Nira aren mengandung beberapa zar gizi antara lain karbohidrat, protein, lemak, dan mineral. Untuk lebih jelasnya dapat dilihat pada Tabel 1 sebagai berikut :

\begin{tabular}{lll}
\multicolumn{3}{l}{ Tabel 1. Komposisi Proksimat Nira Aren } \\
\hline No & Parameter & Hasil (\%) \\
\hline 1. & Air & 91,1 \\
2. & Kadar Abu & 0,28 \\
3. & Protein $(\mathrm{N} \mathrm{x} \mathrm{6,25)}$ & 0,41 \\
4. & Lemak & 0 \\
5. & Karbohidrat & 8,21 \\
6. & Jumlah gula & 0,67 \\
\hline
\end{tabular}

Kandungan air dalam nira aren lebih tinggi yaitu $91,1 \%$ dibandingkan dengan kandungan air yang ada pada gula aren cetak dan gula aren kristal masing-masing 10,28\% dan $3,64 \%$. Hal ini menunjukkan bahwa nira aren memiliki kandungan mineral yang berasal dari tandan bunga jantan. Menurut Hasanah (2017), air dalam nira aren merupakan bagian yang terbesar yang banyaknya antara $75-90 \%$. Air merupakan komponen penting pada suatu bahan pangan yang dapat menentukan kualitas bahan pangan tersebut.
Hasil penelitan memperlihatkan bahwa kadar abu pada nira aren yaitu 0,28\%, sedangkan menurut penelitian Pontoh (2007), kandungan abu pada nira aren yaitu $0,04 \%$. Hal ini menunjukkan bahwa nira aren memiliki kandungan mineral yang tinggi, karena pemanfaatan mineral akan menyebabkan penurunan kadar abu. Dibandingan dengan gula aren cetak dan kristal masing-masing 2,35\% dan $1,88 \%$. Menurut Pontoh (2012), kadar abu yang terdapat pada nira aren bervariasi dari 0,22 sampai dengan $0,98 \%$, sedangkan kadar abu pada gula aren cetak dan kristal tidak jauh berbeda dengan Standar Nasional Indonesia yang menetapkan kadar abu gula aren cetak atau kristal berkisar antara 2,1-2,3\%. Menurut Sluiter et al (2005), kadar abu menunjukkan jumlah kandungan mineral yang terkandung dalam suatu bahan pangan. Jumlah mineral yang dimaksud dapat ditentukan dengan melihat sisa-sisa pembakaran garam mineralnya.

Protein merupakan bagian dalam nira aren, kandungan protein yang terdapat pada nira aren yaitu $0,41 \%$, sementara hasil penelitian Pontoh (2007), bahwa kandungan protein dalam nira aren berkisar pada 0,20$0,61 \%$. Perbedaan ini biasanya karena perbedaan habitatnya. Protein dalam nira aren mempunyai fungsi sebagai enzim. Pada nira aren protein banyak terdapat pada batang tanaman yang diketahui enzim sangat dibutuhkan dalam metabolisme karbohidrat.

Lemak merupakan salah satu golongan lipida. Hasil analisis kandungan lemak pada nira aren yaitu $0 \%$ atau tidak terdapat lemak, sementara hasil penelitian Pontoh (2007), Bahwa kandungan lemak 0,02\%. Keberadaan lemak dalam nira aren disebabkan oleh hasil metabolisme berbagai bagian struktur sel dalam jaringan empulur.

Hasil penelitian memperlihatkan bahwa kandungan karbohidrat nira aren lebih rendah yaitu $8,21 \%$, jika dibandingkan dengan gula aren cetak dan kristal yaitu $84,99 \%$ dan 92,62\%. Menurut Riawan (2017), hal ini juga disebabkan oleh rendahnya kandungan kadar abu, dan lemak yang terdapat pada nira aren, karena kandungan karbohidrat dihitung dari sisa kandungan air, abu, protein dan lemak dari nira aren.

Hasil analisis memperlihatkan bahwa kandungan gula pada nira aren sangat rendah yaitu $0,62 \%$ sementara hasil penelitan Pontoh (2007), perbedaanya sangat jauh yaitu 
kandungan gula pada nira aren berkisar pada $13,9-14,9 \%$. Hal ini disebabkan adanya gula yang dapat menyebabkan nira aren mengalami proses fermentasi menjadi asam, kandungan gula pada nira aren sangat ditentukan oleh adanya mikroorganisme. Menurut Pontoh (2007), gula yang terdapat pada nira aren yang keluar dari pohon akan segera mengalami perubahan dengan adanya mikroorganisme.
Penelitian ini menggunakan 10 orang sebagai responden dengan rincian 4 orang lakilaki dan 6 orang perempuan dalam menentukan indeks glikemik. Responden berumur rata-rata 22,1 tahun, memiliki tinggi badan rata-rata $158,4 \mathrm{~cm}$, Berat badan rata-rata $56,7 \mathrm{~kg}$, dan memiliki IMT normal dengan rata-rata 22,5. Subjek dalam keadaan sehat dan masuk dalam kriteria inklusi. Kerakteristik subjek dapat dilihat dalam Tabel 2.

\section{Karakteristik Responden}

Tabel 2. Karakteristik Subjek Penelitian

\begin{tabular}{cccccc}
\hline No & Jenis Kelamin & $\begin{array}{c}\text { Umur } \\
\text { (Tahun) }\end{array}$ & Tinggi badan $(\mathbf{m})$ & Berat badan $(\mathbf{k g})$ & $\begin{array}{c}\text { Indeks Massa } \\
\text { Tubuh }\left(\mathbf{k g} / \mathbf{m}^{2}\right)\end{array}$ \\
\hline 1. & Perempuan & 22 & 152 & 45 & 20 \\
2. & Perempuan & 22 & 157 & 49 & 19,4 \\
3. & Laki-laki & 22 & 159 & 53 & 21,0 \\
4. & Perempuan & 22 & 149 & 47 & 23,1 \\
5. & Perempuan & 22 & 154 & 54 & 23 \\
6. & Perempuan & 23 & 148 & 50 & 24 \\
7. & Laki-laki & 21 & 173 & 71 & 24,4 \\
8. & Perempuan & 22 & 154 & 58 & 24,5 \\
9. & Laki-laki & 23 & 175 & 75 & $22,5 \pm 1,73$ \\
10. & Laki-laki & 22 & 163 & 65 &
\end{tabular}

\section{Penentuan Jumlah Pangan Uji}

Pengujian indeks glikemik dilakukan dengan memberikan sampel pangan standar (glukosa murni) dan pangan uji (nira aren) yang mengandung available karbohydrate setara dengan 25 gram glukosa murni dan karbohidrat sampel $8.21 \%$. Berdasarkan hasil perhitungan diatas maka jumlah sampel pangan uji yang akan diberikan pada responden adalah 304,5 $\mathrm{mL}$ setiap orang responden.

\section{Nilai Indeks glikemik nira aren}

Indeks glikemik merupakan nilai yang menunjukkan kemampuan dalam suatu makanan yang mengandung karbohidrat yang dapat meningkatkan kadar glukosa darah Arif dkk (2013),. Hasil penelitian menunjukkan bahwa rata-rata glukosa darah responden yang diberi glukosa murni pada menit ke-0, 30, 60, 90, dan 120 menit, berturut- turut $93,2 \mathrm{mg} / \mathrm{dL}$, $155,4 \mathrm{mg} / \mathrm{dL}, 124,2 \mathrm{mg} / \mathrm{dL}, 93,8 \mathrm{mg} / \mathrm{dL}$ dan $79,1 \mathrm{mg} / \mathrm{dL}$ (Gambar 1). Sementara itu, ratarata kadar glukosa responden yang diberi nira aren rata-rata pada menit ke-0, 30, 60, 90 dan 120 berturut-turut $81,8 \mathrm{mg} / \mathrm{dL}, 118,6 \mathrm{mg} / \mathrm{dL}$, $92,6 \mathrm{mg} / \mathrm{dL}, 74,1 \mathrm{mg} / \mathrm{dL}$, dan $63,7 \mathrm{mg} / \mathrm{dL}$. Menurut Widowati dkk (2009), kadar glukosa darah normal berkisar antara 55-140 mg/dL, dan untuk penyediaan energi bagi susunan syaraf pusat diperlukan kadar glukosa darah minimal 40-60 mg/dl. Gula darah akan meningkat setelah makan yang umumnya pada pagi hari berada pada level terendah (Mufti dkk, 2015). Hasil penelitian menunjukkan, pada menit ke-30 kadar gula darah responden meningkat atau dalam keadaan tidak normal setalah mengkonsumsi glukosa murni. Hal ini menurut Triana (2017), ketika mengkonsumsi karbohidrat tubuh akan memberikan reaksi dengan memberikan sinyal kepada pankreas, hormon ini bekerja layaknya kunci, membuka sel tubuh dan membiarkan glukosa untuk masuk kedalam sel sehingga glukosa dapat dibakar dalam suatu reaksi untuk menghasilkan energi. Bila kadar glukosa meningkat, maka sel-sel $\beta$-pankreas akan melepaskan insulin. Hormon ini akan bekerja dalam meningkatkan kecepatan pemecahan glukosa melalui proses glikolisis, meningkatnya sintesis glikogen dari glukosa didalam hati dan otot, dan meningkatnya sintesi lipida dan protein dari glukosa.

Kadar glukosa darah responden meningkat pada menit ke-30, tetapi pada menit 
ke-60 kadar gula darah responden menurun. Hal ini sama dengan hasil penelitian yang ditunjukan oleh Indrasari (2008), perubahan kadar glukosa darah mencapai puncak pada menit ke-30 dan mulai menurun pada menit ke60 setelah mengkonsumsi makanan yang diuji. Bila kadar glukosa darah menurun, maka sel-sel $\alpha$-pankreas akan melepaskan glukagon. Menurut Triana (2017), hormon ini akan bekerja dalam memperlambat pemasukan glukosa kedalam sel-sel jaringan, dan meningkatkan laju pemecahan glikogen menjadi glukosa didalam hati, meningkatkan laju pemecahan lemak dan protein menjadi turunannya untuk digunakan dalam proses glukoneogenesis, serta meningkatkan laju reaksi glukoneogenesis yaitu pembentukan glukosa dari asam lemak atau asam amino. Konsumsi glukosa murni memberikan efek cepatnya perubahan naik dan turunnya kadar glukosa darah setelah 2 jam konsumsi.

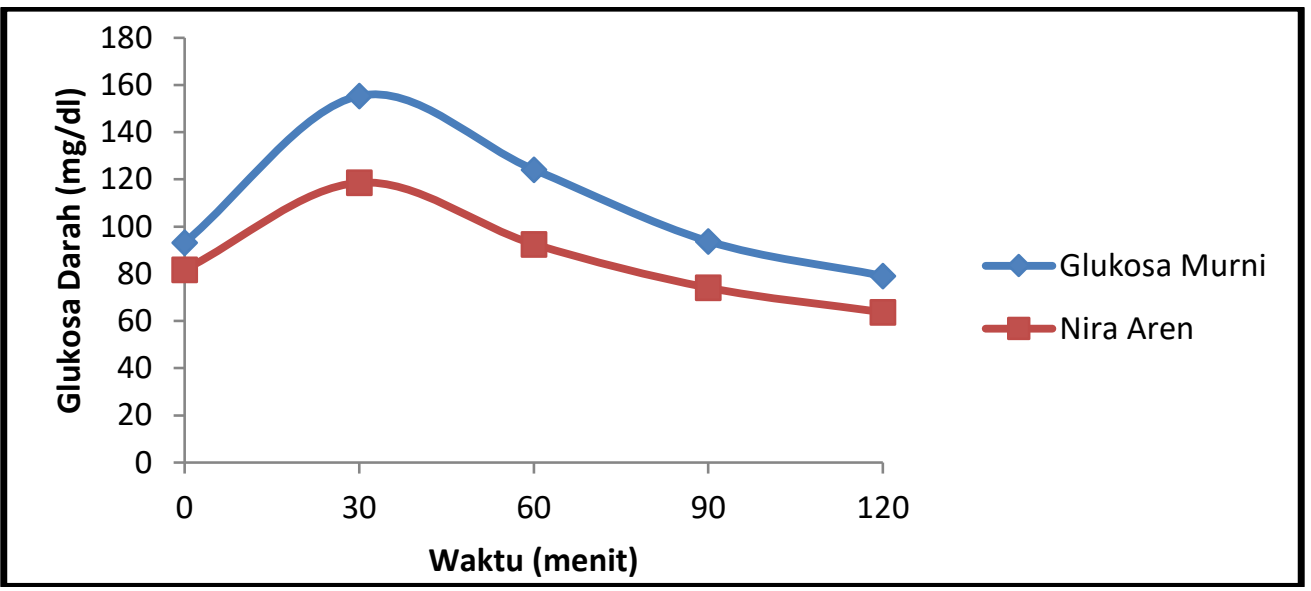

\section{Gambar 1: Kurva Perubahan Glukosa Darah Responden Setelah Mengkonsumsi} Glukosa Murni dan Nira Aren.

Hasil yang didapatkan nira aren memiliki nilai IG yaitu 35,56 , yang berarti bahwa karbohidrat yang berada pada nira aren diabsorbsi tubuh secara lambat sehingga meningkatkan glukosa darah lambat. Menurut Istiqomah (2015), berdasarkan respon glikemiknya pangan dibedakan menjadi 3 kelompok, yaitu pangan ig rendah $(<55)$, ig sedang (55-70), dan ig tinggi (>70). Jika dibandingkan dengan gula aren cetak dan kristal diketahui bahwa gula aren cetak memiliki ig sedang yaitu yaitu 62,47 dan gula aren kristal memiliki nilai indeksi glikemik rendah yaitu 43,61. Menurut Hoerudin (2012), pangan yang berindeks glikemik rendah dan indeks glikemik tinggi dapat dibedakan berdasarkan kecepatan penyerapan dan pencernaan glukosa serta fluktuasi kadarnya dalam darah. hal ini didukung oleh pendapat lain. Menurut Dini (2014), pangan berindeks glikemik rendah akan dicerna dan diubah menjadi glukosa secara bertahap serta perlahanlahan, maka puncak kadar glukosa darah akan rendah, yang berarti fluktuasi peningkatan kadar glukosa relatif pendek. Hal ini sengat penting bagi penderita diabetes dalam mengendalikan kadar gula darah. Sebaliknya pangan berindeks glikemik tinggi akan dicerna dalam tubuh dan akan dirubah menjadi glukosa secara cepat. Menurut Arif dkk (2013), menyatakan bahwa pangan berindeks glikemik rendah mengalami proses pencernaan lambat, karena laju pengosongan perut berlangsung secara lambat. Hal ini disebabkan oleh suspense pangan (chyme) lebih lambat mencapai usus kecil, sehingga penyerapan glukosa pada usus kecil menjadi lambat. Akhirnya, fluktuasi kadar glukosa darah pun relatif kecil. Sebaliknya pangan berindeks glikemik tinggi dicirikan laju pengosongan perut, pencernaan karbohidrat dan penyerapan glukosa yang berlangsung secara cepat, sehingga fluktuasi kadar glukosa darah juga relatif tinggi. Hal ini karena penyerapan glukosa sebagian besar hanya terjadi pada usus kecil bagian atas. Hal ini sengat penting bagi para olahragawan yang akan melakukan pertandingan dimana membutuhkan makanan yang dapat dengan cepat dikonveksi menjadi energi. Faktor- faktor 
yang mempengaruhi IG diantaranya yaitu protein dan lemak (Widowati, 2007).

Kandungan lemak dan protein dapat mempengaruhi nilai indeks glikemik. Hal ini pangan dengan kadar lemak yang tinggi cenderung memperlambat laju pengosongan lambung, sehingga laju pencernaan makanan pada usus halus juga lambat. Sementara itu, kadar protein yang tinggi diduga merangsang sekresi insulin (Arif, 2013), sehingga glukosa dalam darah tidak berlebih dan terkendali. Oleh karena itu, pangan dengan kandungan lemak dan protein tinggi cenderung memiliki IG lebih rendah dibandingkan dengan pangan sejenis yang berkadar lemak dan protein rendah (Rimbawan dan Siagian 2004). Menurut Oku et al. (2010) menyatakan bahwa pangan dengan IG rendah dapat menghasilkan banyak energi jika mengandung banyak lemak dan protein. Namun, pangan berlemak harus dikonsumsi secara bijaksana. Total konsumsi lemak tidak boleh melebihi $30 \%$ dari total energi dan total konsumsi lemak jenuh tidak melebihi $10 \%$ dari total energi (Arif, 2013). Berdasarkan hasil penelitian kandungan lemak pada nira aren yaitu $0 \%$ atau tidak terdapat lemak, jika dibandingan dengan gula aren cetak dan kristal masing-masing memiliki kandungan lemak $0,50 \%$ dan 0,58\%. Menurut Pontoh (2012), kandungan lemak ada pada gula aren cetak dan kristal ini berasal dari hasil metabolisme berbagai bagian struktur sel dalam jaringan empulur tanaman. Kandungan protein pada nira aren relatif rendah yaitu $0,41 \%$, jika dibandingkan dengan kandungan protein pada gula aren cetak dan kristal masing-masing $1,91 \%$ dan $1,28 \%$. Kadar protein dalam suatu bahan pangan didasarkan pada total protein (crude protein) (Riawan, 2017).

Indeks glikemik merupakan suatu cara untuk memberikan gambaran tentang hubungan antara karbohidrat dalam makanan dengan respon glukosa darah. Makanan yang memiliki nilai IG rendah dapat memperlambat absorbs karbohidrat. Makanan yang berindeks glikemik rendah akan dicerna dan diubah menjadi glukosa secara bertahap dan perlahan-lahan, sehingga puncak kadar glukosa relatif pendek, oleh karena itu untuk mengendalikan kadar gula darah dianjurkan untuk mengkonsumsi makanan dengan nilai indeks glikemik rendah.

Apabila seseorang mengkonsumsi pangan dengan glikemik tinggi maka akan memicu sekresi insulin lebih banyak dari pada pangan yang berindeks glikemik rendah karena akan terjadi hiperglikemia postprandial dan meningkatnya level incretin, yaitu hormon yang berperan dalam stimulasi sekresi insulin, sehingga terjadi hiperinsulinemia yang menyebabkan resistensi insulin (Hoerudin, 2012).

\section{KESIMPULAN}

Berdasarkan hasil penelitian dapat di simpulkan bahwa :

1. Nira aren mengandung $91,1 \%$ air, $0,28 \%$ kadar abu, $0,41 \%$ protein, $0 \%$ lemak, $8,21 \%$ karbohidrat dan $0,67 \%$ jumlah gula.

2. Nira aren memiliki indeks glikemik yang termasuk kategori rendah, yaitu 35,56. Pangan yang berindeks glikemik rendah akan dicerna dan diubah menjadi glukosa secara bertahap dan perlahan-lahan maka puncak kadar gula relatif pendek, sehingga nira aren dapat menjadi minuman alternatif untuk menjaga kadar gula darah.

\section{UCAPAN TERIMA KASIH}

Penulis menyampaikan terima kasih kepada Badan Penelitan dan Pengembangan Industri Balai Besar Agro, Bogor, yang telah membantu dalam menganalisi proksimat, Klinik Pratama Civika Universitas Negeri Gorontalo yang telah membantu dalam pengambilan glukosa darah, Laboratorium Biologi Fakultas Matematika dan Ilmu Pengetahuan Alam Universitas Negeri Gorontalo, dan mahasiswa jurusan biologi yang telah bersedia menjadi responden dalam pengambilan darah.

\section{REFERENSI}

Arif , A. Bin, Budiyanto, A. Hoerudin. 2013. Nilai Indeks Glikemik Produk Pangan Dan Faktor-Faktor Yang Memengaruhinya. Bogor. J. Litbang Pertanian. Vol 32.

Barclay, A.W. Petocz, P. Price, J. M, Flood, V.M, Prvan, T. Mitchell, P. and Miller, J. C Brand. 2008. Glycemic Index, Glycemic Load, and Chronic Diseases. American. 87:627-37.

Budijanto, S., Andry, Y. A., Faridah, D. N., Noviasari, S. 2017. Karakterisasi Kimia dan Efek Hipoglikemik Beras Analog Berbahan Dasar Jagung, Sorgum, dan Sagu Aren. Bogor. Agritech. Vol 37(4). 
Brouns F, Bjorck I, Frayn K.N, Gibbs A.L, Lang V, Slama G, Wolever T.M. Glycaemic Index Methodology. Nutrition Research Reviews. 2005; 18: 145-171.

Dini, R,Z., dan Rustanti, N. 2014. Pengaruh Substitusi Tepung Ampas Kelapa Terhadap Nilai Indeks Glikemik, Beban Glikemik, dan Tingkat Kesukaan Roti. Journal of Nutrition College. Vol 3 (1): $213-221$

Hasanah, Siti, Z., 2017. Pengaruh Perbandingan Gula Merah Cair Dan Nira

Terhadap karakteristik Gula Semut (Palm Sugar). Artikel. Universitas Pasundan : Bandung.

Hoerudin, 2012. Indeks glikemik buah dan implikasinya dalam pengendalian kadar glukosa darah. Buletin Teknologi Pascapanen Pertanian. Vol 8 (2).

Indrasari, S.D., Purwani, E.Y., Wibowo, P., dan Jumali., 2008. Nilai Indeks Glikemik Beras Beberapa Varietas Padi. Jurnal Penelitian Pertanian Pangan. Balai Besar Penelitian Tanaman Padi. 27 (3): 129.

Istiqomah, Annisa., Rustanti., N. 2015. Indeks Glikemik, Beban Glikemik, Kadar Protein, Serat, Dan Tingkat Kesukaan Kue Kering Tepung Garut Dengan Substitusi Tepung Kacang Merah. Universitas Diponegoro : Semarang. Journal of Nutrition College. Vol 4(2).

Lestari, O, A., Dewi, Y,K., dan Purwayantie, S. 2017. Indeks Glikemik (IG) dan Beban Glikemik (BG) Olahan Buah Etnik Kalimantan Barat Cempedak dengan Teknologi Penggoreng Vakum. Seminar Nasional Penerapan Ilmu Pengetahuan dan Teknologi. Pontianak

Mufti, T., Dananjaya, R., Yuniarti, L., 2015. Perbandingan Peningkatan Kadar Glukosa Darah Setelah Pemberian Madu, Gula Putih, dan Gula Merah Pada Orang Dewasa Muda yang Berpuasa. Prosiding Penelitian Sivitas Akademika Unisba (Kesehatan).

Murray, R. K., Granner, D. K., \& Rodwell, V. W. 2009. Biokimia harper (27 ed.). Jakarta: Buku Kedokteran EGC;
Nielsen SS. 2010. Food Analysis. $4^{\text {th }}$ ed. New York (USA): Springer Science + Business Media

Oku,Tsuneyuki, N. Mariko, and N. Sadako. 2010. Consideration of the validity of glycemic index using blood glucose and insulin levels and breath hydrogen. Int'1. J. Diabetes Melitus (2): 88- 94

Ostman, E. M, 2001. Reguler of produk "Inconsistency between glycemic and insulinemic responses", American Journal of Clinical Nutrition. 74:96100

Pontoh, J. 2007. Analisa Komponen Kimia dalam Gula dan Nira Aren. Sulawesi Utara, Tomohon: Laporan pada Yayasan Masarang.

Pontoh, Julius. Gunawan, I. dan Fatimah, F. 2011. Analisa Kandungan Protein Dalam Nira Aren. J Chem Prog. Universitas Sam Ratulangi : Manado. Vol 4(2)

Pontoh. 2012. Aren Untuk Pangan Dan Alternatif Energi Terbarukan. Prosiding seminar nasional aren. Balikpapan (ID): Agroinovasi

Price, S.A., dan Wilson, L. M., 2005, Patofisiologi: Konsep Klinis Prosesproses Penyakit, Edisi 6, vol 2, diterjemahkab oleh penerbit Vol, B. U., Hartanto, H., Wulansari, p., Mahanani, D. A.,Penerbit Buku Kedokteran EGC, Jakarta.

Riawan, A. 2017. Indeks Glikemik Gula Aren Cetak Dan Kristal. Skripsi. Institut Pertanian Bogor : Bogor.

Riccardi, G., Rivellese, A.A. \& Giacco, R., 2008. Role of Glycemic Index and Glycemic Load in the Health State, in Prediabetes, and in Diabetes. Am $\mathrm{j}$ Clin Nutr, 87(1)

Rimbawan \& Siagian, A., 2004. Indeks Glikemik Pangan. Jakarta: Penebar Swadaya.

Sluiter A, Hames B, Ruiz R, Scarlata C, Sluiter J, Templeton D. 2005. Determination of Ash in Biomass. Colorado: Department of Energy Office of 
Energy Efficiency and Renewable Energy.

Standar Nasional Indonesia. 1992. Cara Uji Gula. SNI 01-2892-1992

Standar Nasional Indonesia. 1992. Cara Uji Makanan dan Minuman. SNI 01-28911992

Triana, L., Salim, M., 2017. Perbedaan Kadar Glukosa Darah 2 Jam Post Prandial. Analisis kesehatan polteknes kemenkes Pontianak : Pontianak. Jurnal Laboratorium Khatulistiwa. Vol. 1(1).
Widowati, S. 2007. Pemanfaatan ekstrak teh hijau ( Camellia Sinensis O. Kuntze) dalam pengembangan beras fungsional untuk penderita diabetes melitus. Disertasi. Sekolah Pascasarjana Institut Pertanian Bogor.

Widowati, S., Santosa, B. A. S., Astawan, M., dan Akhyar., 2009. Penurunan Indeks Glikemik Berbagai Varietas Beras Melalui Proses Pratanak. J. Pascapanen. 6 (1) : 7.

Widyawati, N. 2012. Sukses investasi masa depan dengan bertanam pohon aren. Lily Publisher. Yogyakarta. 